\title{
Adoption of Conservation Agriculture in Zambia - The Case of Chongwe District
}

\author{
Abson Chompolola $^{1} \&$ Oliver Kaonga ${ }^{1}$ \\ ${ }^{1}$ Department of Economics, University of Zambia, Lusaka, Zambia \\ Correspondence: Abson Chompolola, Department of Economics, University of Zambia, Box 32379, Lusaka, \\ Zambia.Tel: 260-211-290-475. E-mail:abson.chompolola@unza.zm
}

$\begin{array}{lc}\text { Received: February 16, } 2016 & \text { Accepted: March 5, } 2016 \quad \text { Online Published: May 30, } 2016 \\ \text { doi:10.5539/jsd.v9n3p77 } & \text { URL: http://dx.doi.org/10.5539/jsd.v9n3p77 }\end{array}$

\begin{abstract}
The Zambian government and its cooperating partners have been trying to promote the use of conservation agriculture for improved food security and promotion of environmental sustainability. The methods used to promote conservation agriculture however are not adequately informed because no Zambia-specific studies have been done to explain adoption behaviour. This study aimed at explaining the factors that affect the adoption of conservation agriculture in Zambia using a case study.

A cross section survey of 200 randomly selected small scale farmers in Chongwe district was conducted using a structured questionnaire. Information collected included demographic characteristics of participating households, economic, as well as social characteristics. Respondents also provided information on the farming practices they are currently using vis a vis conservation agriculture.

A decision model was estimated using logistic regression and the results indicate that the adoption of conservation agriculture in the survey area is basically influenced by ownership of draft power, availability of labour, and the frequency of contact with the farmer support extension system. Potential to increase the adoption rate is plenty, but can only be tapped into if strategies and policies take into account the behavioural aspects of the adoption of the technology.
\end{abstract}

Keywords: conservation agriculture, technology adoption, zero tillage, zambia

\section{Introduction}

Conservation agriculture (CA) has been practiced in Zambia from as far back as the 1930s. Since then, a number of initiatives to encourage the practice and other related sustainable agricultural technologies have come and gone. The promotion and practice of conservation agriculture is premised on the promise of environmental sustainability, increased agricultural productivity, and enhanced food security associated with it (FAO, 2009).

$\mathrm{CA}$ is a combination of crop production practices which include minimum tillage, mulching, use of composite and green manure, planting in pits and intercropping, crop rotation and integrated crop management (Tripp, 2006). A combination of these practices insures minimal disturbance of the environment while guaranteeing increased soil productivity. This form of agriculture is therefore of great appeal to both members of the green revolution and those obsessed with issues of sustained food security and improved agricultural productivity. CA as practiced in Zambia consists of a package of five key principles: (i) reduced tillage on more than 15\% of the field area without soil inversion, (ii) precise digging of permanent planting basins or ripping of soil with a Magoye ripper (where draft animals are available), (iii) leaving of crop residues on the field (no burning), (iv) rotation of cereals with legumes and (v) dry season land preparation (CFU 2007).

In spite of its long history in Zambia and its associated benefits, CA was only adopted as official policy of the Zambian government in the year 2000 (MAFF, 2001). Conservation farming is seen as a better alternative to traditional farming methods whose excessive use of chemicals, monoculture orientation, and intensive tillage of land has been blamed for poisoning of the environment, loss of biodiversity, and general degradation of the soil with the consequent loss of soil productivity (Crosson, 1992, and Baudron et al. 2007). In the case of Zambian, the promotion and adoption of conservation farming methods can be attributed to two main reasons; (i) agricultural activities among small and medium farmers in the country is hugely dependent on rains with very few farmers using irrigation systems. However, the country has in the past experienced periods of drought. As 
such, farmers are in need of viable and more sustainable farming methods to remain productive amid these climatic challenges; (ii) following the removal of subsidies on agricultural inputs, intensive farming become unaffordable for the majority of small and medium scale farmers. CA technology presented a cost effective way of farming while maintaining the same level of productivity.

The promotion of conservation agriculture and related practices in Zambia has had both success and failures. Kabamba et al (2009), in a case study on conservation agriculture in the KapiriMposhi district of Zambia, reported that about $91 \%$ of the farmers in the case study were using some components of CA but only $10 \%$ were applying the whole package of conservation farming. In another study done by the Jesuit Centre for Theological reflections in Chongwe District, it was reported that $96 \%$ of the farmers interviewed knew about conservation farming and $78 \%$ of them were using some of its components (JCTR, 2011). The JCTR study further established that even among the adopters, the proportion of cultivated land that was under conservation agriculture was less than $50 \%$ and $60 \%$ of the adopters had less than two hectares of cultivated land under CA. A FAO publication of 2009 put the number of farmers practicing conservation agriculture in Zambia at 100, 000 and total area under $\mathrm{CA}$ at 110, 000 (FAO, 2009). This implies that on average, each of the farmers involved had about 1 hectare of land under CA. Other estimates indicate that adoption as of the year 2010 was at 270,000 farmers, which is about $21 \%$ of the target farming community (Simasiku et al, 2010). Given the long history of conservation agriculture in Zambia, one would have expected a bigger proportion of farmers adopting the practice.

On a positive note however, there is anecdotal evidence indicating that about $60 \%$ of the country's districts, many of which lie in agro-ecological zones I and II (figure 1), have so far received sensitisation and training in the methods of conservation farming. These two agro-ecological zones have been associated with poorer rainfall patterns than areas in region III. Other reports indicate that seven of the nine provinces in the country have received active support for CA (Baudron et al. 2007). This shows that a lot has been done to sensitize people on the importance and benefits of CA. The question however is, given the long history of conservation farming in the country and, most importantly, the promotional activities that have been carried out to enhance its adoption, "why has full adoption or adoption at all been elusive"?

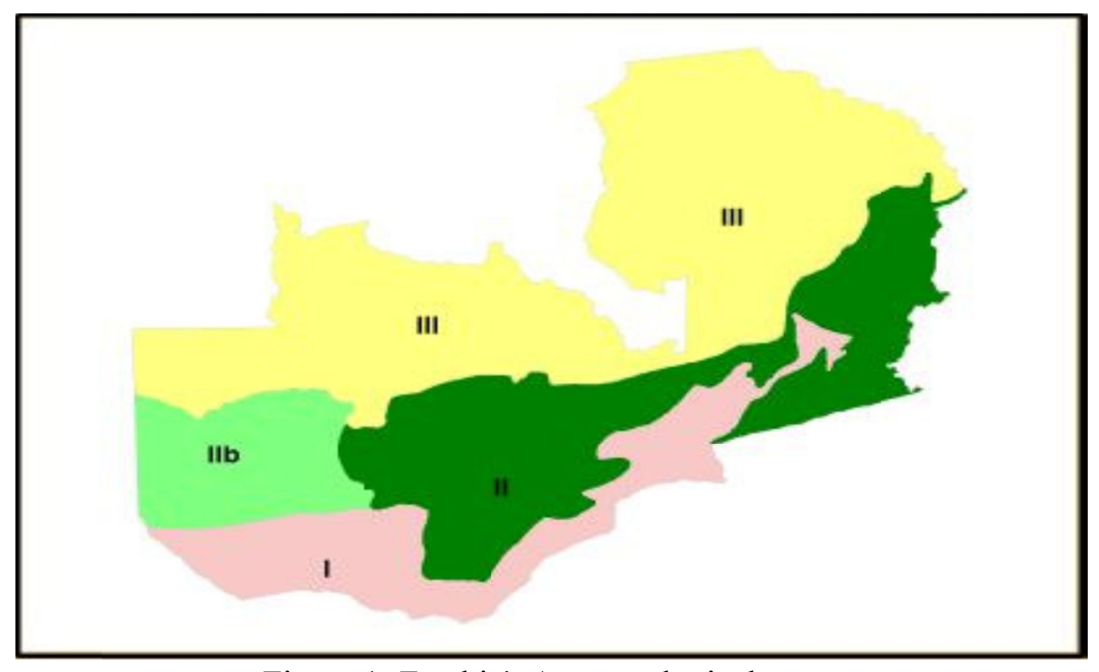

Figure 1. Zambia's Agro-ecological zones

\subsection{Study Rationale}

The seemingly slow progress in the adoption of CA has not discouraged the Ministry of Agriculture in its resolve to continue promoting the practice. The ministry has targeted to have $50 \%$ of all small-scale farmers trained in conservation agriculture by the year 2015 and $35 \%$ of them should be practicing CA by 2015 (JCTR, 2011). The commitment to this cause is evidenced by the continued budgetary allocation to the promotion of CA technologies.

While the resolve to continue promoting CA is a noble one, its success cannot be guaranteed unless strategies are evidence-based. Without evidence, the targets that have been set by the Ministry of Agriculture will be elusive. This study set out to unravel the circumstances that predispose farmers to adopt or not to adopt CA. The motivation was to enhance knowledge of farmer's decision behaviour and provide an opportunity for informed policies and strategies formed around the promotion of not only CA, but also other agricultural technologies that 
may come in future. The apparent lack of similar studies in Zambia provided additional motivation for this study.

\subsection{Theoretical Underpinning of the Adoption of Agricultural Technology}

The adoption of agricultural technology by small holder farmers has been explained in terms of three main conceptual models. These models, as explained by Negatu and Parikh (1990), include the innovation-diffusion model, the economic constraints model, and the technology characteristics-user's context model.

The innovation-diffusion model attributes technology adoption to availability of and access to information. It posits that once transferred to potential end-users, the adoption of technology depends on the personal characteristics of the potential individual user (Kormawa et. al. 2004). Information dissemination is therefore paramount in all efforts to promote technology given that adoption decision depends on access to information.

The economic constraints model attributed to Hayami and Ruttan (1971) assumes that the distribution of resource endowments among the potential users in a region determines the pattern of adoption of a technological innovation. The motivation of individuals is profit or utility maximization using available resources. But these resources are not distributed symmetrically among potential adopters of technology implying that adoption decisions will also be varied among potential adopters facing different economic circumstances (Adesina and Baidu-Forson, 1995; Negatu and Parikh, 1999).

The technology characteristics-user's context model argues that the adoption of technology depends on its characteristics as well as on the agro-ecological, socio-economic and institutional contexts within which potential users find themselves (Scoones and Thomson, 1994). This model highlights the importance of perceptions of potential users in determining adoption or non adoption of technology. The model implies that adoption of technology can be enhanced by involving farmers in the development of technology so that the technologies developed will have greater appeal to the farmers.

The conceptualization of this study as a technology adoption investigation was motivated by all the three conceptual models of technology adoption, but the economic constraints model and the technology characteristics-user context model were of greater significance. Since farmers are assumed to be rational consumers of agricultural technologies, their preferences will be shaped by their perception of the products' attributes (Adesina and Bardu-Forson, 1995). Additionally, their decision to adopt an innovation is a behavioral response arising from a set of opportunities and constraints they face (Leagans, 1979). Institutional arrangements could for instance constrain adoption just as much as resource constraints would.

\section{Methods}

\subsection{Study Area}

The study was conducted in a rural district in Zambia called Chongwe. The district lies in the country's agro-ecological zones associated with relatively poor rainfall patterns. On average, the area receives between 800 and $1000 \mathrm{~mm}$ of rain per year. Chongwe is predominantly a farming area populated with mostly subsistence farmers growing maize and other cash crops including groundnuts, cotton, and beans. The average cultivated land ranges from 0.5 to 4 hectares.

For administrative and operational purposes, Chongwe is divided into 5 zones and these zones are further divided into 28 agricultural camps. The camps are administrative geographical units created by the Ministry of Agriculture for convenience in the administration of extension services. Each camp on average has 1,691 households.

\subsection{Sampling and Data Collection}

The data used for this study were collected from two of the farming camps in the study area. Camp selection for this study was done purposively; only camps which had received sensitization on the practice and benefits of conservation farming were eligible for the study. This was done to rule out cases of non-use as a result of ignorance of CA. Proportionate samples were drawn from the two camps using systematic random sampling. A total of 200 households were selected from a possible total of about 2,300 households. Cross section data were gathered using a structured questionnaire. The information gathered was on both qualitative and quantitative attributes of the farmers vis a vis their practice of conservation agriculture, and their social economic attributes.

\subsection{Data Analysis}

Logit and probit models have been used extensively to investigate adoption behavior of economic agents (Adeogun et al, 2008; Kormawa et al, 2004; Adesina et al, 1995). The two models will normally take dichotomous kind of responses. In this case, the responses will be ' 1 ' if a person has adopted the technology in question and ' 0 ' otherwise. This study specially used the logit model to understand the binary choices of adoption and non-adoption 
of conservation agriculture in the survey area. The model enables one to both estimate the probability of a farmer adopting a practice given his/her circumstances, and distinguish the change in the odds of adoption when circumstances change (Ramsey and Schafer, 1997).

The logit model was selected because it is easy to handle in terms of computational requirements (Adeogun et al, 2008, and Gujarati, 1995), and has been found to be efficient in explaining dichotomous decision variables (Grisley, 1994). According to Madala (1992), the probit and logit models take the following general form;

$$
y_{i}^{*}=\beta_{0}+\sum_{j=1}^{k} \beta_{j} x_{i j}+u_{i}
$$

In this model, $y_{i}^{*}$ is unobserved; what is observed is a dummy variable $y_{i}$ defined by:

$$
y_{i}= \begin{cases}1 & \text { if } \mathrm{y}^{*}>0 \\ 0 & \text { otherwise }\end{cases}
$$

If the disturbance term $u_{i}$ in equation 1 is logistically distributed, we have a logit model which when expressed in terms of odds gives the logit which takes the following form;

$$
\frac{\text { Probability of event }}{\text { Probability of no event }}=\frac{P}{1-P}=e^{\beta_{0}+\sum_{j=1}^{k} \beta_{j} x_{i j}+u_{i}}
$$

In this particular case, $P$ is the probability that a farmer will adopt conservation farming, and $1-P$ means the opposite. To estimate the logit model, the dependent variable is transformed by taking natural logarithms of both sides to yield the following:

$$
\log \frac{P}{1-P}=\beta_{0}+\sum_{j=1}^{k} \beta_{j} x_{i j}+u_{i}
$$

The left hand side of equation 4 is called the log-odds ratio. In this case it gives the log of the ratio of farmers who adopt conservation farming to those that do not adopt the practice.

The decision model for farmers was empirically estimated as follows:

$$
\begin{aligned}
& \log \frac{P}{1-P}=\beta_{0}+\beta_{1} \text { Age }+\beta_{2} \text { Education }+\beta_{3} H H \text { size }+\beta_{4} \text { Income }+\beta_{5} \text { Land ownership }+\beta_{6} \text { Extensioncontacts }+ \\
& \beta_{7} \text { Cattle owned }+\beta_{8} \text { Experience }+\beta_{9} \text { Sex of HH head }+u_{i}
\end{aligned}
$$

\subsection{Variables and Hypothesised Relationships}

The dependent variable was the dichotomous "adopt" or "do not adopt" conservation agriculture. Adoption was defined as having practiced conservation agriculture before, regardless of whether one was still practicing or not. Out of the 200 households surveyed, 77 percent had practiced conservation agriculture before. The proportion adopting the technology was higher among male ( 80 percent) than female ( 71 percent) headed households. It was hypothesized that female headed households would most likely adopt the technology compared to male counterparts given that the technology was more labor intensive and women tend to provide most of the labor for food production (Mutune et al., 2011).

Education level was defined as the highest level of education attained by the head of the household. The level of education in this case was defined as, and measured in terms of, the number of years of schooling that a person has done. It was hypothesized that higher level of education would positively influence the decision to adopt the technology. The argument here is that education gives farmers the capacity to easily acquire and comprehend new information and, hence prompts them to demand and utilize complex agricultural technologies (Mutune et al., 2011; Sarungbam, 2011). High levels of education also tend to make farmers less risk averse thus, enabling them to try out new innovations (Chuma et al., 1998). In addition, conservation farming technologies are knowledge intensive and are therefore most likely to be adopted by the reasonably educated (Wall, 2007). The average schooling of respondents in the survey was generally low; an aspect that may not support adoption given the knowledge intensiveness of the technology. The average schooling for adopters was only 8 years of 
education.

Age was defined and measured as the number of completed years of the head of the household. The impact of age on adoption behaviour however is indeterminate. On one hand, following studies on technology adoption done elsewhere, it was envisaged that age would have a negative effect on adoption behaviour; older farmers are less willing to adopt new technologies while younger farmers, being more knowledgeable about new practices, are willing to take risks (Adeogun et al., 2008; and Polson et al., 1991). On the other hand, older farmers may be in a better position to adopt new technologies due to their comparative advantage in terms of capital accumulated, number of extension contacts, and credit worthiness (Langyintuo and Mekuria, 2005). The survey results show that respondents were middle aged, and this could support technology adoption. Adopters of the technology had an average age of 48 years.

Sex was treated as a dummy variable representing the sex of the head of household, where male $=1$, and female $=0$. The impact of sex on adoption decision is indeterminate. Female-headed households were expected to adopt technologies more easily than their male counterparts due to labour demands of conservation farming (Blackden and Bhanu, 1998). Conservation tillage practices are labour intensive in the initial years and women provide most of the labour for food production (Mutune et al., 2011). This makes it more likely that female headed households will adopt conservation farming than families headed by their male counterparts. A counter hypothesis however is that female headed households are less likely to adopt conservation farming because of limited resources and gender discrimination in extension message delivery (Langyintuo and Mungoma, 2008). Limited resources mean that female headed households have a challenge in making the initial investment required when adopting new technologies.

Availability of farm labour was measured as the number of able bodied members in the household aged 10 years and above. It was envisaged that the propensity to adopt conservation farming would increase with household size due to increased labour resources. Larger families are less constrained by the huge demand for labour that conservation farming entails in the initial years. Additionally, smallholder farmers have a low propensity to hire labour outside their farms because they are resource constrained. They mainly use family labour to do most of the farm work (Erenstein, 1997). The surveyed sample had sizeable endowment of labour averaging 5 people of working age per household. This was expected to have positive effect on adoption decision.

The amount of livestock that households have was expected to have a mixed effect on adoption behaviour. Shiferaw and Holden (1998) argue that livestock as a form of wealth offers farmers a sense of security which enhances adoption. On the other hand, intense animal husbandry may reduce demand for conservation agricultural technologies because crop production in this case becomes a secondary enterprise. In the case of this study, the farmers in the study area practice animal husbandry mainly as a source of draft power. Animal husbandry can therefore not be viewed as a substitute enterprise to crop farming but a complement. It was therefore anticipated that animal holding would enhance adoption of zero tillage. Descriptive statistics show that the sampled households were not well-endowed in terms of cattle ownership; each household had an average of 2 cows. Ownership of cattle was higher among non-adopters than adopters.

Annual income was used as one of the proxies for economic status which was envisaged to have a positive effect on adoption behaviour. This hypothesis is premised on the argument that lack of cash or access to cash may deter smallholder farmers from adopting new technologies that require initial investments (Doss et al., 2003). Table 1 shows that the annual income for adopters was very varied but averaged K6, 367.00 (about USD1, 248. 43). It is indeterminate whether this amount of income is sufficient for a household to subsist on and have excess to invest in new farming technology or not. But one sure thing is that the income suggests the sampled households were not well-off in terms of income.

Farming experience was measured in terms of the number of years of farming experience of the household head. The caveat here was to measure experience from the time the farmer became a decision maker on his own field (Mueller et al., 1988, and Adeogun et al., 2008). Based on empirical studies done elsewhere, it was envisaged that the number of years of experience in farming would enhance the likelihood of adoption. According to Frank (1997) individuals assess the utility of new practices by relating their perception of the practice to their experience. Technology adopters in this study had an average of 19 years of farming experience. The amount of experience and adoption status is quite consistent with results from empirical studies done elsewhere.

The size of the farmer's farm was determined as the total amount of farm land owned measured in hectares. It was envisaged that farmers with bigger land holdings would have more capacity to experiment with new technologies, first on smaller scale as they carry on with their usual practice on the larger part of the farm, and later switch from conventional practice (Kaumbutho and Kienzle, 2007; and Mutune et al., 2011). Additionally, 
Mutune et al., (2011) argues that larger farm sizes are associated with wealth and therefore farmers may plant perennial crops, leaving capacity for the practice of conservation tillage on nurse crops on the same piece of land. This increases the propensity of farmers to adopt conservation farming. Results from this study reveal that households surveyed were not marginal farmers; this is reflected in the fact that the average land-holding was close to three hectares. This amount of landholding justifies the adoption status of the technology adopters.

Contact with extension officers was measured as the number of times a farming household was visited by extension officers in a year. The number of contacts was expected to increase the likelihood of adoption of conservation agriculture. This is because extension officers are traditionally the major vehicle for technology promotion as well as provision of support services once technology has been adopted. According to Sarungbam and Prasad (2011) non-awareness of new technology increases the chance of not adopting new technology. Increased contact with the extension system is therefore expected to lead to increased awareness and heightened propensity to adopt new technology. The survey results show that there were more contacts with extension officers among adopters than non-adopters. Adopters on average had contact with the extension system six times in a year.

Table 1. Descriptive statistics of variables in the empirical model $(\mathrm{N}=154)$

\begin{tabular}{llcc}
\hline Variable & Description & Mean & SD \\
\hline HHSIZE & Household members who work on the farm & 4.7 & 2.1 \\
CATTLE & Amount of cattle owned representing draft power & 1.9 & 4.3 \\
EXTENSIONCONTACT & Contact with extension officers in a year & 6.0 & 4.0 \\
EXPERIENCE & Number of years of farming experience & 18.5 & 9.8 \\
EDUCATION & Number of years of schooling & 8.1 & 2.5 \\
INCOME & Average annual income & 6,367 & 7,300 \\
FARMSIZE & Total amount of farm land owned in hectares & 2.6 & 1.4 \\
AGE & Number of completed years & 47.7 & 12.3 \\
\hline
\end{tabular}

\section{Estimated Results for the Adoption Model}

Estimates of the coefficients for the decision model for adoption of zero tillage are presented in table 2. The chi-square statistic for the model was significant at 5 percent indicating that the model is okay; all the coefficients in the model are not equal to zero. This confirms that the variables included in the model are relevant in explaining farmer's decision to adopt or not to adopt zero tillage.

The parameter estimates obtained indicate that adoption decision in the case of zero tillage is influenced significantly by only three of the eight variables in the model; these variables include the availability of labor (HHSIZE), draft power (CATTLE), and the level of interaction with the extension system (EXTENSIONCONTACT).

The variables EXPERIENCE, SEX, EDUCATION and INCOME possessed the hypothesized coefficients but were not statistically significant. The coefficient for AGE is positive implying that the odds of adopting zero tillage increases with age. Our results are inclined to the hypothesis that older farmers may be in a better position to adopt new technologies due to their comparative advantage in terms of capital accumulated and number of extension contacts. The variable FARMSIZE had a wrong coefficient and was also not significant.

The economic variable HHSIZE had a positive and statistically significant coefficient at 5 percent, suggesting that households with more labor were more likely to adopt conservation agriculture than those with less amount of labor. This result is consistent with what Mutune et al (2011) obtained in a study on the adoption behavior of farmers in Kenya. The explanation for this is that zero tillage is quite labor intensive, especially in the initial stages of adoption. The results also indicate that a unit increase in labor at household level increases the odds of adopting zero tillage by the factor 1.3 .

Another statistically significant economic variable was the availability of draft power measured in terms of the amount of cattle owned by a household. The variable CATTLE was significant at 5 percent but had a negative coefficient, indicating that farmers with more cattle were less likely to adopt conservation agriculture. This finding however should be interpreted with caution given that cattle ownership in the study area had a lot of variations as 
suggested by the standard deviation in table 1 . This caveat, notwithstanding, the results in the table below indicate that the odds of adopting CA reduce by the factor 0.86 for a unit increase in the amount of cattle owned.The negative coefficient is contrary to the results suggested by Shiferaw and Holden (1998), and Kormawa et al (2004). Qualitative interviews with the farmers indicated that ploughs used in zero tillage were not easily accessible on the market and this acted as a deterrent in the adoption of the technology by farmers. Others still argued that it was easier for farmers without draft power to adopt zero tillage since they could access hoes more easily than farmers with draft power could access ripping ploughs.

The institutional/sociological variable EXTENSIONCONTACT was statistically significant at 5 percent and also had the expected positive coefficient. This implies that farmers with more contacts with the extension system have higher propensity to adopt conservation agriculture. The switch from conventional to conservation farming requires careful planning by farmers to avoid disruptions in food security. Most farmers are reluctant to effect such changes in the absence of strong extension support. In terms of the odds of adoption, a unit increase in the number of contacts with extension officers increases the odds of adoption of zero tillage by the factor 1.23. This result is consistent with what was found in Kenya (Mutune et al., 2011) and Nigeria (Adeogun et al., 2008).

Table 2. Coefficients of the Logistic regression model for adoption

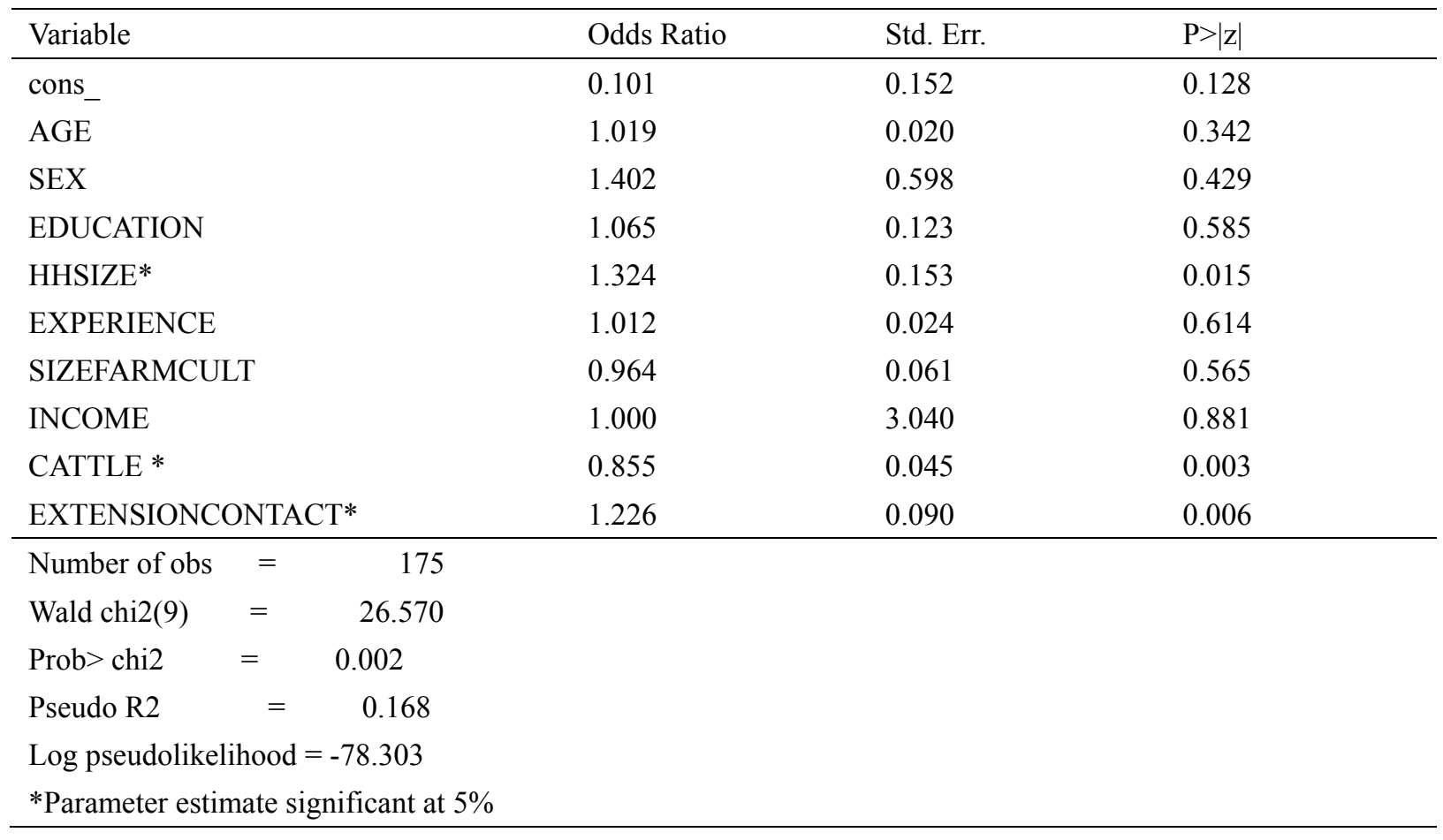

\section{Conclusion and Recommendations}

This study used logistic analysis to identify factors which explain the adoption of CA in one of the rural districts of Zambia. Necessitating the analysis is the fact that while CA is very old in the country, the practice has not received widespread acceptance among farmers it is meant to benefit. Understanding adoption behavior in the target group therefore becomes an important ingredient in policies and efforts aimed at increasing the acceptance and adoption of CA.

The analysis shows that there are basically three variables significantly influencing farmers' decision to adopt zero tillage and these include ownership of cattle, contact with the extension system, and availability of labor at the household level. This implies that the adoption of zero tillage can actually be promoted by directing strategies towards these variables. The recommendations to enhance adoption of zero tillage are therefore as follows:

Given that labor availability is a significant influence on adoption of zero tillage; it is important that potential users are made to understand that contrary to perception, the practice is actually labor-saving in the long run. Once the initial investment in the technology has been made, the labor requirement will reduce in subsequent 
years. This message will help convert farmers that are daunted by the seeming huge labor requirements in the initial stages of adoption.

The extension system should be streamlined to enhance dissemination of information. Stakeholders involved in the promotion of conservation agriculture should put efforts together with government to expand provision of extension services. This could be through training to increase the number of extension officers so that the unmet need for their services among farmers is reduced.

Ownership of draft power has a negative influence on adoption of the technology. The challenge here is that appropriate draft powered equipment for zero tillage is not readily available. This makes it difficult for would-be adopters to switch from conventional farming. The already existing equipment like the 'Magoye Ripper' should be more accessible financially as well as geographically, to address both supply and demand side constraints.

Generally, there is a lot of potential for improvement and having more and more farmers adopting CA. The benefits of CA, as was highlighted in the background section, are immense both at individual/household level and at national level.

\section{Acknowledgements}

The authors would like to extend their sincere gratitude to the directorate of Research and Graduate Studies of the University of Zambia for the financial support to the data collection.

\section{References}

Adeogun O. A., Ajana A.M., Ayinla O. A., Yarhere M. T., \&Adeogun M. O. (2008). Application of LogitModel in Adoption Decision: A Study of Hybrid Clarias in Lagos State, Nigeria.American-EurasianJournal of Agriculture \& Environmental Science, 4(4), 468-472.http://idosi.org/aejaes/jaes4\%284\%29/10.pdf

Adesina, A. A., \& Baidu-Forson, J. (1995). Farmers' perceptions and adoption of new technology, evidence from analysis in Burkina Faso and Guinea, West Africa.Agricultural Economics, 13, 1-9. Retrieved from http://impact.cgiar.org/pdf/230.pdf

Baudron, F., Mwanza,H.,Triomphe,B., \& Bwalya, M. (2007).Conservation agriculture in Zambia: a case study of Southern Province. African Conservation Tillage Network (ACT), Nairobi, Food and AgricultureOrganization of the United Rations. Retrieved fromhttp://www.fao.org/ag/ca/doc/zambia_casestudy.pdf

Blackden, C. M., \&Bhanu, C. (1998).Gender, growth and poverty reduction: Special programme of assistance for Africa. In collaboration with the poverty and social policy working group of the special programme of assistance for Africa. World Bank Technical Paper No. 428. World Bank Washington, D.C. Retrieved from http://wwwwds.worldbank.org/servlet/WDSContentServer/WDSP/IB/1999/06/04/000094946_9904120637 099/Rendered/PDF/multi_page.pdf

CFU.(2007). Conservation Farming and Conservation Agriculture Handbook for Hoe Farmers in Agro-Ecological Regions I and IIa.Retrieved March 11, 2016, fromhttp://www.fsnnetwork.org/sites/default/files/conservation_agriculture_cf_handbook_forhoe_farmers zambia.pdf

Chuma, R., Benites, J., Fowler, J., KienzleNyangumbo, K., Steiner, R., \&Molopong, J. (1998).Conservation tillage for sustainable agriculture.International workshop, Harare Zimbabwe. Deutsche Gesellschaft, Eschborn Germany.

Crosson, P. (1992). Sustainable food and fiber production. Presented at the annual meeting of the American Association for the Advancement of Science, Chicago, February 9, 1992.

Doss, C., Mwangi,W.,Verkuijl,H., \& de Groote, H. (2002).Adoption of maize and wheat technologies in Eastern Africa: A synthesis of the findings of 22 Case Studies.CIMMYT.Retrieved from http://impact.cgiar.org/sites/default/files/pdf/52.pdf

Doss, C., Mwangi,W.,Verkuijl,H., \& de Groote, H. (2003).Adoption of maize and wheat technologies in Eastern Africa: A synthesis of the findings of 22 Case Studies.CIMMYT. Retrieved from http://www.fao.org/docs/eims/upload/163121/Adoption\%20of\%20Maize\%20and\%20Wheat\%20Technologi es\%20in\%20Eastern\%20Africa.pdf

Erenstein, O. (1997). The adoption of conservation tillage in a hillside maize production system in Motozintla, Chiapas. Natural Resource Group. Mexico. CIMMYT. Retrieved from http://repository.cimmyt.org/xmlui/bitstream/handle/10883/945/64142.pdf 
Frank B. R. (1997). Constrained limiting innovation adoption in northern Queensland beef industry.A socio-economic means of maintaining a balanced lifestyle. Agricultural Systems, p. 49. Retrieved from http://www.sciencedirect.com/science/article/pii/0308521X9590745F

Grisley, W. (1994). Farmer-to-Farmer transfer of new crop varieties: an empirical analysis of small farms in Uganda.Agricultural Economics, $11(1)$.Retrieved from http://ageconsearch.umn.edu/bitstream/173439/2/agec1994v011i001a004.pdf

Gujarati, D. N. (1995).Basic Econometrics(3rded.). McGraw-Hill, Singapore.

Hayami, Y., \&Ruttan, V. W. (1971).Agricultural development: an international perspective. Johns HopkinsUniversity Press, Baltimore.

JCTR. (2011). Study on Knowledge, Attitudes and Practices on Conservation and Organic farming in Zambia. The Jesuit Centre for Theological Reflection, Lusaka.

Kabamba, H., \&Muimba-Kankolongo, A. (2009).Adoption and impact of conservation farming on crop productivity among smallholder farmers in KapiriMposhi District of Zambia.Journal of Animal \& Plant Sciences, 3(2), 205-214. Retrieved fromhttp://www.m.elewa.org/JAPS/2009/3.2/4.pdf

Kaumbutho, P., \&Kienzle, J. (Eds.). (2007). Conservation agriculture as practised in Kenya: two case studies. Nairobi. African Conservation Tillage Network, Centre de CoopérationInternationale de RechercheAgronomique pour le Développement, Food and Agriculture Organization of the United Nations. Retrieved from http://www.fao.org/ag/ca/doc/kenya_casestudy.pdf

Kormawa P. M., Ezedinma C. I., \& Singh B. B. (2004).Factors Influencing Farmer-to-Farmer Transfer of an Improved Cowpea Variety in Kano State, Nigeria.Journal of Agriculture and Rural Development in the Tropics and Subtropics, 105(1), 1-13. Retrieved from http://jarts.info/index.php/jarts/article/viewFile/46/40

Langyintuo, A., \&Mekuria, M. (2005).Modeling agricultural technology adoption using software stata, IMMYT. Harare, Zimbabwe.

Leagans, J.P. (1979). Adoption of modern agricultural technology by small farm operators.Cornell international agricultural mimeograph No. 69, Cornell University, New York.

Madala, G. S. (2001). Introduction to Econometrics(3rded.).Cambridge University Press.

Ministry of Agriculture, Food and Fisheries. (2001). Conservation farming and land use: 5-year programme proposal for the ASIP Successor Programme.Lusaka: MAFF.

Mueller, R. A. E., \& Jansen, H.G.P. (1988).Farmers and farm concepts in measuring adoption lags.Journal of Agricultural Economics, 39(1), 121-124. http://dx.doi.org/10.1111/j.1477-9552.1988.tb00567.x

Mutune, J., Mburu, J., Nyikal, R., \&Kironchi, G. (2011). Determinants of adoption of conservation tillage practices in maize-cowpea cropping systems: The case of Makueni District, Kenya.Journal of Soil Science and Environmental Management, 2(11), 354-361. Retrieved from http://www.academicjournals.org/article/article1379600717_Mutune\%20et\%20al.pdf

Negatu, W., \& Parikh, A. (1999). The impact of perception and other factors on the adoption of agricultural technology in the Moret and JiruWoreda (district) of Ethiopia.Agricultural Economics, 21, 205-216. http://dx.doi.org/10.1016/S0169-5150(99)00020-1

Polson, R. A., \& Spencer, D. S. C. (1991). The technology adoption process in subsistence agriculture: the case $\begin{array}{lllll}\text { of cassava in South Western Nigeria.Agricultural Systems, } 36, & \text { 65-77. }\end{array}$ http://dx.doi.org/10.1016/0308-521X(91)90108-M

Sarungbam, D., \& Prasad, Y. E. (2011). Factors affecting adoption of mono-cropping of rice in Manipur: A Logistic Approach.Agricultural Economics Research Review, 24(2) 333-337. Retrieved from http://ageconsearch.umn.edu/bitstream/119411/2/17-D-Sarungbam.pdf

Scoones, I., \& Thomson, J. (1994).Knowledge power and agriculture - towards a theoretical understanding. InI.Scoones, \& J.Thomson (Eds.),Beyond farmer first: rural people's knowledge and extension practice.Intermediate Technology Publications, London.

Shiferaw, B., \& Holden, S.T. (1998).Resource degradation and adoption of land conservation technologies in the Ethiopian highlands: A Case Study in AnditTid, North Shewa.Agricultural Economics, 18, 233-247. http://dx.doi.org/10.1016/S0169-5150(98)00036-X

Simasiku, P., Chapoto, A., Richardson, R., Sichilongo, M., Tembo, G., Weber, M., \& Zulu, A. (2010). Natural 
resource management, food security, and rural development in Zambia: Moving from research evidence to action; Food security project.Working Paper $\quad$ No. $\quad$ 44.Retrieved fromhttp://pdf.usaid.gov/pdf_docs/Pnadt432.pdf

Tripp, R. (2006). Is low external input technology contributing to sustainable agricultural development? Natural Resources Perspectives No. 102, ODI, London. Retrieved fromhttps:/dlc.dlib.indiana.edu/dlc/bitstream/handle/10535/4075/102-low-external-input-technology-sustai nable-agricultural-development.pdf? sequence $=1$

Wall, P.C. (2007). Tailoring Conservation Agriculture to the needs of small farmers in developing countries: An analysis of issues.Journal of Crop Improvement, $19(1 / 2)$ Retrieved fromhttps://www.researchgate.net/publication/232887148_Tailoring_Conservation_Agriculture_to_the_Nee ds_of_Small_Farmers_in_Developing_Countries

\section{Copyrights}

Copyright for this articleis retained by the author(s), with first publication rights granted to the journal.

This is an open-access article distributed under the terms and conditions of the CreativeCommons Attribution license (http://creativecommons.org/licenses/by/3.0/). 